\title{
Tooth Coronal Pulp Index as a Tool for Age Estimation in Egyptian Population
}

\section{El Morsi $\mathrm{DA}^{1}$, Rezk $\mathrm{HM}^{2}$, Aziza $\mathrm{A}^{3}$ and El-Sherbiny $\mathrm{M}^{4}$}

${ }^{1}$ Department of Forensic Medicine \& Clinical Toxicology, Mansoura University, Egypt

${ }^{2}$ Department of Anatomy, Mansoura University, Egypt and Department of Anatomy, Batterjee Medical College

(BMC), Jeddah, KSA

${ }^{3}$ Bachelor of Dental Surgery (BDS), Faculty of Oral and Dental Medicine, Mansoura University, Egypt

${ }^{4}$ Department of Anatomy, Mansoura University, Egypt \& Department of Medicine, Almaarefa Colleges, Riyadh, KSA

${ }^{*}$ Corresponding author: El Morsi DA, Department of Forensic Medicine and Clinical Toxicology - Mansoura Faculty of Medicine, Egypt, E-Mail: dr.doaa2014@outlook.com

Citation: El Morsi DA, Rezk HM, Aziza A, El-Sherbiny M (2015) Tooth Coronal Pulp Index as a Tool for Age Estimation in Egyptian Population. J Forensic Sci Criminol 3(2): 201. doi: 10.15744/2348-9804.2.501

Received Date: March 02, 2015 Accepted Date: April 28, 2015 Published Date: April 30, 2015

\begin{abstract}
Age estimation from tooth - coronal index (TCI) using dental radiographs based on reduction in the size of the dental pulp cavity with advancing age as a result of secondary dentin deposition, has been presented. The study aimed to assess the accuracy of age estimation from TCI of mandibular premolars and molars (except wisdom teeth) of both sides using panoramic radiographs of known age and sex and to develop regression equations that can be used in the Egyptians. The study was conducted on 234 Egyptian subjects (119 males and 115 females) of known age and sex. The length of tooth crown and that of coronal pulp cavity (in $\mathrm{mm}$ ) of 845 mandibular premolars and 835 mandibular molars were measured. Then TCI was computed for each tooth and regressed on the real age of the sample. The results reveal that the mean \pm SE age of the studied subjects is $25.52 \pm 0.84$ years (ranges from 8 to 74 years). There is no difference in TCI between both sexes. TCI for premolars is larger than those of molars and it is higher in males than females ( $27.24 \pm 0.077$ to $28.51 \pm 0.755$ in females; $27.26 \pm 0.748$ to $28.66 \pm 0.846$ in males); and ( $24.79 \pm 0.763$ to $28.44 \pm 0.680$ in females; $24.81 \pm 0.835$ to $29.45 \pm 0.866$ in males) respectively. Also there is highest significant correlation of the $2^{\text {nd }}$ right premolar TCI with age $(\mathrm{p} \leq 0.05)$. It could be concluded that TCI method of mandibular teeth was found to be the best radiologic; rapid and non - invasive method for age estimation and the regression equations should be applied cautiously for different populations and time periods.
\end{abstract}

Keywords: Age estimation; Teeth; Tooth pulp; TCI; Dental radiograph; Identification

\section{Introduction}

In forensic science; identification of a person is a fundamental question. It is an important basis for legal and ethical issues and declaration of death reports. Also there is an increasing demand for age estimation in living persons to clarify criminal and civil liability and social issues [1,2]. One of the most reliable methods for age estimation in forensic science is based on teeth examination. Teeth are the hardest part of the body and could be preserved for a long time after death without gross changes [3-6]. Different methods for teeth examination; morphological, biochemical and histological; could be used [7-9].

However these methods are invasive and require tooth extraction [10-15]. Furthermore; non-invasive radiographic techniques have been developed for measurements of the reduction in the dental pulp cavity associated with advancing age due to secondary dentin formation [16-19].

Once tooth crown is fully formed secondary dentin begins to form. Dentin formation continues throughout life, and layers of secondary dentin (also known as regular secondary dentin) are continuously deposited by odontoblasts lining the pulp chamber [20]. Since regular secondary dentin is laid down at the pulpal end of the primary dentin, the pulp cavity decreases in size with age. If dentin is exposed to acute damage, for example dental caries, some of the underlying odontoblasts die, this irritation or response dentin is often known as irregular secondary dentin, and sometimes referred to as tertiary dentin [21,22].

Teeth consist of enamel as the outermost covering of tooth crown and dentin underneath, both of which are hard tissues resistant to decomposition, followed by pulp as the innermost soft tissue core. Likewise cementum is the outermost covering for the surface of root which is also resistant to decomposition [9,23,24]. Age estimation in children and adolescents can be performed with a standard technique given by Schour and Massler's [25]; Demirijian's method [26] and Ikeda et al. [27]. Gustafson's method is still in practice by the forensic odontologists in medicolegal issues, he evalueted the extent of six changes correlated teeth with increasing age. These are: the degree of attrition, the position of epithelial attachment, the amount of secondary dentine, the cemental thickness, the degree of root resorption and the transparency of root dentine; although a lot number of modifications to this method have been described [28]. 
These modifications were done by Kilian's method [29] which is based on the evaluation of six markers: the degree of attrition, the secondary dentin, the secondary cementum, the resorption, the transparency and the position of epithelial attachment. However, Kashyap and Koteswara [30]; modified Gustafson's criteria to make it more objective; it is based on the quantitative evaluation of four markers: the abrasion, the secondary dentin, the secondary cementum and the transparency.

Since 2004, Cameriere et al. [31-33] have studied method of age estimation using the pulp/tooth area ratio to quantify the apposition of secondary dentin. The method has elicited more interest than others and has been tested on different teeth. Moreover, as stated by Bashet et al. [16] radiographic evaluation of secondary dentin may be the only non-invasive approach to estimate age from fully developed teeth.

On the other hand Kvaal et al. [34] introduced a radiographic method in which tooth extraction was not required as it was done by indirectly measuring deposition of secondary dentin (by measuring pulp radiolucency) and correlated it to age. The study of Ikeda et al. [27] measured the tooth-coronal index (TCI) [Tooth - Crown index = Length of the coronal pulp cavity / Length of the Crown X 100] after it was computed for each tooth and regressed on real age. In 1993, Drusini [20] following Ikeda et al. method, soft X-ray photos were taken to measure the length (in $\mathrm{mm}$ ) of the crown (CL) and the length of coronal pulp cavity (CPCL). Then, the coronal index was computed for each tooth and regressed to obtain equations that allow estimation of age in unknown bodies and isolated teeth [21].

Many of these studies have discussed methods based on measurements on various radiographic and morphological parameters and developed formulas on such basis [33]. However, the reproducibility of these parameters is uncertain, as the values may be different for individuals from different ethnical groups [35].

The present study aims to assess the accuracy of age estimation from tooth - coronal index (TCI) of mandibular premolars and molars (except wisdom teeth) of both sides using panoramic radiographs of known age and sex individuals and to develop regression equations that can be used in the Egyptians.

\section{Subjects and Methods}

\section{Samples}

This study was conducted on a total of 234 Egyptian subjects (119 males \& 115 females) with 1680 intact teeth of known age and sex. They were subjected to panoramic radiographs after taken written informed consent. These panoramic radiographs were provided by a private radiologist (Hyperion X7, MYRAY - Imola, Italy). The panoramic radiographs were chosen because most of intraoral films were exposed to reveal pathologies such as caries and inflammatory process. But with panoramic radiographs it is possible to select teeth free from pathology with a distinct pulp chamber. The advantages of using panoramic X-ray photographs are: 1) Cutting the teeth is not necessary; 2) Panoramic X-ray is a very common dental-test, so it could be examined in a short time; 3) All the mandibular and the maxillary teeth are on one film; 4) Gross lesions (fractures, unerupted teeth) are readily visible. 5) Vertical measurements had acceptable accuracy and reproducibility when a software-based calibrated measurement tool was used [36]. Panoramic X-ray shows a lack of detail in comparison with the intraoral radiography, especially for the anterior teeth, and the projection can only be taken at one angle. For these reasons, the posterior teeth where the pulp chamber is normally fully visible were only chosen, disregarding all the pathological specimens $[21,24]$. The exposure parameters were set according to the patient's age and size. The patient's identification number, sex, age and date of radiographic taking were recorded. The exclusion criteria were: subjects with any developmental, endocrine or nutritional disorder and special dental diseases. Also panoramic radiographs showing impacted teeth, teeth with root canal treatment, crown restorations, broken teeth, teeth with large areas of enamel overlap between neighboring teeth, missing one of the studied teeth or unclear radiographs were excluded.

The study included 845 mandibular premolars (394 from males and 451 from females) and 835 mandibular molars (393 from males and 442 from females) of both sides (with exclusion of wisdom teeth) because they were more visible than maxillary teeth as suggested by Drusini et al. [24]. Protocol of the study was approved by Ethical Committee of Faculty of Medicine, Mansoura University.

\section{Measurements}

On all photographs with a fully visible pulp cavity two measurements were taken (Figures 1, 2). Height of the crown (CH) and height of the coronal pulp cavity $(\mathrm{CPCH})$. Then tooth - coronal index $(\mathrm{TCI})$ for each tooth was calculated as follows: $\mathrm{TCI}=$ CPCH X 100 / CH. The use of an index instead of absolute measurement excludes possible errors resulting from different scales of $\mathrm{X}$ - ray photos (Drusini $[21,24]$ ). All measurements were taken using image processing software (ImageJ) to the nearest 0.01 $\mathrm{mm}$. To ensure the accuracy of the technique used for measuring TCI a detailed reference points used: Cervical line that connect two landmarks to be measured; the mesial and distal cementoenamel junction points; and divides the tooth into crown and root. Crown height is the maximum perpendicular distance from the cervical line to the tip of the highest cusp of teeth. While pulp height is the distance from cervical line to the coronal tip of the pulp chamber. All measurements were carried out twice by two observers and the mean was recorded to minimize intra and inter - observer errors. 

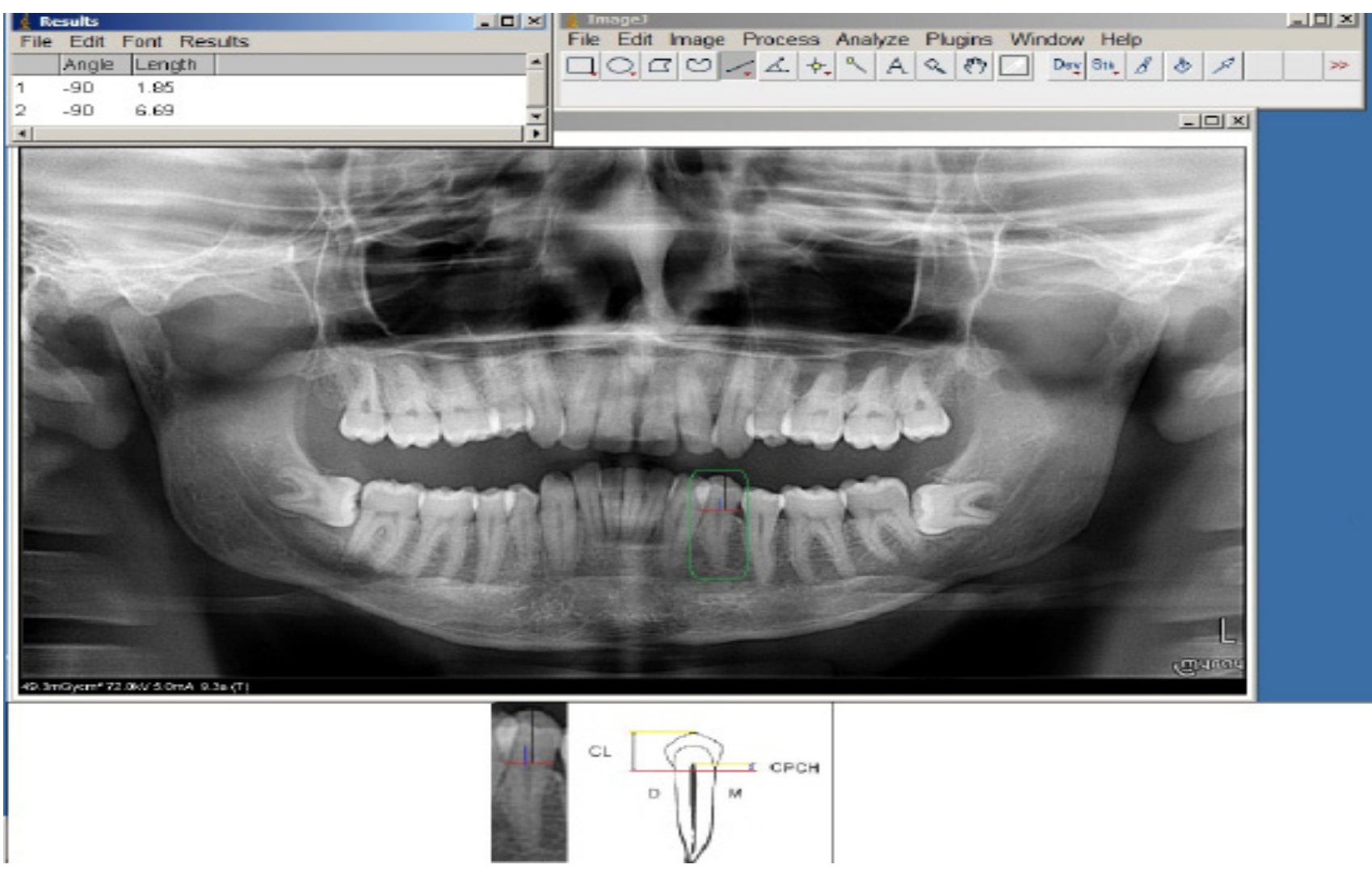

Figure 1: Premolar panoramic X - ray shows the measurements of TCI. The transverse line (red) represents the cementoenamel junction between crown and root. The black line represnts crown height $(\mathrm{CH})$ and blue line represnts coronal pulp cavity height $(\mathrm{CPCH}) . \mathrm{D}=$ distal side and $\mathrm{M}=$ mesial side
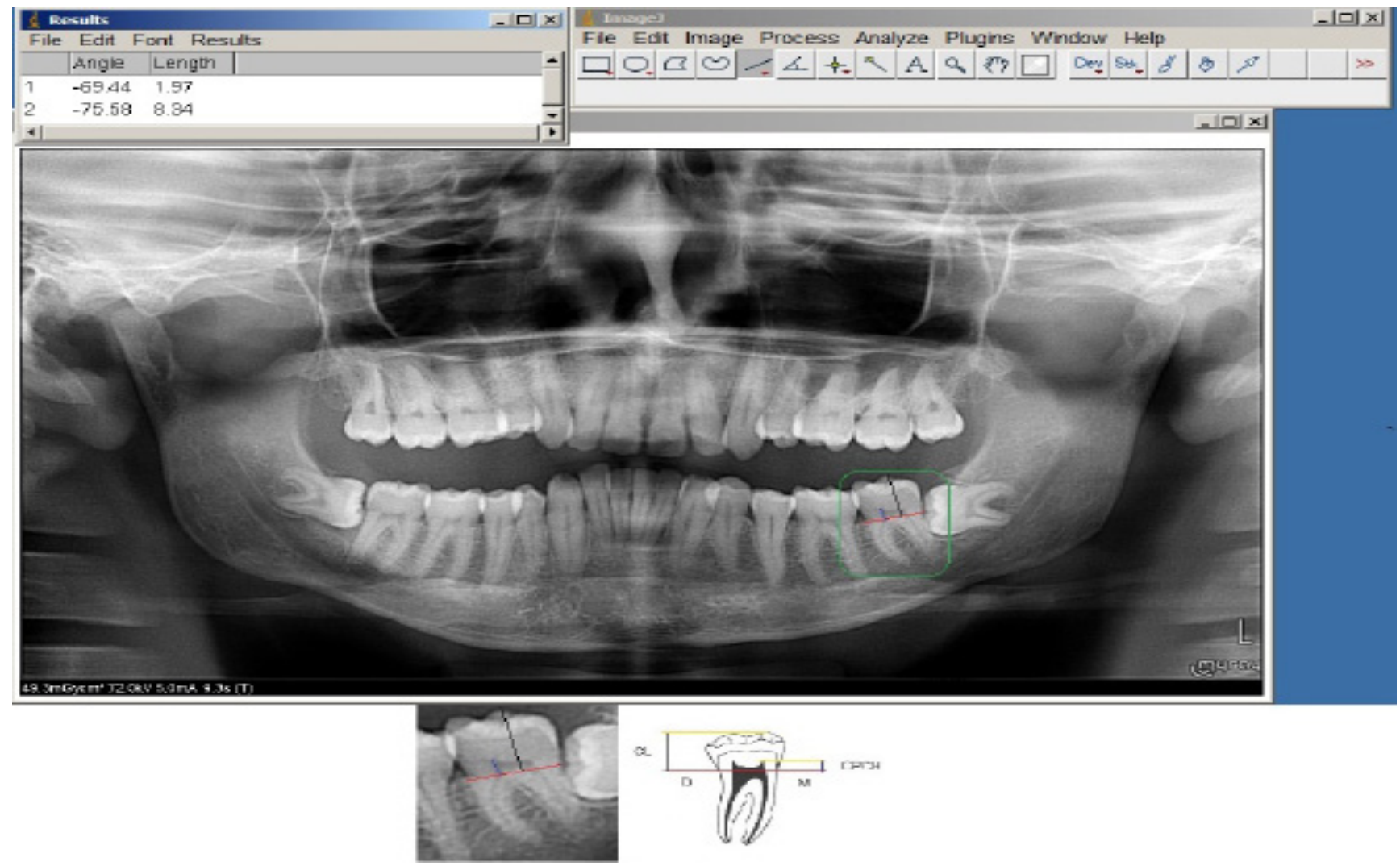

Figure 2: Molar panoramic X -- ray shows the measurements of TCI. The transverse line (red) represents the cementoenamel junction between crown and root. The black line represnts crown height $(\mathrm{CH})$ and blue line represnts coronal pulp cavity height $(\mathrm{CPCH})$. $\mathrm{D}=$ distal side and $\mathrm{M}=$ mesial side 


\section{Statistical Analysis}

The statistical analysis of data done by using excel program for figures and SPSS (SPSS, Inc, Chicago, IL) program statistical package for social science version 17. The description of the data done is in the form of mean (+/-) SE for quantitative data; frequency \& proportion for qualitative data.

The analysis of the data was done to test statistical significant difference between groups. For quantitative date, student t-test was used to compare between two groups. Repeated measure ANOVA to compare same group in different times followed by post Hoc test for intra-time comparison. Pearson correlation was done to detect the association between two continues variables. Linear logestic regression was done to predict unknown variable (age) by using teeth measurements significant in univarate analysis. Inter and intra - observer agreements were determined using non-parametric -t- test.

N.B: $\mathrm{p}$ is significant if $\leq 0.05$ at confidence interval $95 \%$.

\section{Results}

The paired t-test to evaluate potential observer error revealed no statistically significant intra- and inter-observer differences between the paired sets of measurements carried out on the re-examined panoramic radiographs $(\mathrm{p}>0.05)$.

Descriptive analysis of the studied subjects by means of age $(n=234)$ are summarized in Table 1 . The mean \pm SE age of the studied subjects is $25.52 \pm 0.84$ years (ranges from 8 to 74 years). Males represent $50.9 \%$ with mean \pm SE age of $28.43 \pm 1.27$ years; while females represent $49.1 \%$ with mean \pm SE age of $22.49 \pm 11.04$ years.

\begin{tabular}{|c|c|c|c|c|c|}
\hline Gender & Mean + SE & Min & Max & T & $\mathrm{p}$ \\
\hline Males $(\mathrm{n}=119)(50.9 \%)$ & $28.43 \pm 1.27$ & 8.4 & 74 & 3.61 & $<0.001^{* * *}$ \\
\hline Females $(\mathrm{n}=115)(49.1 \%)$ & $22.49 \pm 11.04$ & 8 & 55 & & \\
\hline Total $(\mathrm{n}=234)(100 \%)$ & $25.51 \pm 0.84$ & 8 & 74 & & \\
\hline
\end{tabular}

$\mathrm{SE}=$ Standard error; $\mathrm{Min}=$ minimum; $\mathrm{Max}=$ maximum; $\mathrm{p}<0.05$ is considered significant

Table 1: Descriptive Statistics of the Studied Subjects by Means of Age ( $\mathrm{n}=234)$

Comparison of tooth - coronal index (TCI) of the right and left teeth between both sexes are demonstrated in Table 2 . There is no significant difference between sex and TCI. Also the mean of TCI for premolars is larger than those of molars and it is higher in males than females $(27.24 \pm 0.077$ to $28.51 \pm 0.755$ in females; $27.26 \pm 0.748$ to $28.66 \pm 0.846$ in males); and ( $24.79 \pm 0.763$ to 28.44 \pm 0.680 in females; $24.81 \pm 0.835$ to $29.45 \pm 0.866$ in males) respectively.

\begin{tabular}{|c|c|c|c|c|}
\hline $\begin{array}{c}\text { Gender } \\
\text { Tooth (TCI) }\end{array}$ & $\mathbf{N}$ & Mean $\pm \mathrm{SE}$ & $t$ & p \\
\hline $\begin{array}{c}\text { Right 1st premolar }\left(4^{\text {th }}\right) \\
\text { Male } \\
\text { Female }\end{array}$ & $\begin{array}{l}103 \\
112\end{array}$ & $\begin{array}{c}28.22 \pm 0.802 \\
28.51 \pm .0 .755\end{array}$ & $0.262-$ & 0.793 \\
\hline $\begin{array}{c}\text { Left 1st premolar }\left(4^{\text {th }}\right) \\
\text { Male } \\
\text { Female }\end{array}$ & $\begin{array}{c}96 \\
112\end{array}$ & $\begin{array}{l}27.26 \pm 0.748 \\
28.92 \pm 0.811\end{array}$ & -1.494 & 0.137 \\
\hline $\begin{array}{c}\text { Right 2nd premolar }\left(5^{\text {th }}\right) \\
\text { Male } \\
\text { Female }\end{array}$ & $\begin{array}{c}99 \\
115\end{array}$ & $\begin{array}{l}28.66 \pm 0.846 \\
28.23 \pm 0.748\end{array}$ & 0.376 & 0.707 \\
\hline $\begin{array}{c}\text { Left } 2 \text { nd premolar }\left(5^{\text {th }}\right) \\
\text { Male } \\
\text { Female }\end{array}$ & $\begin{array}{c}96 \\
112\end{array}$ & $\begin{array}{l}28.57 \pm 0.802 \\
27.24 \pm 0.777\end{array}$ & 1.185 & 0.237 \\
\hline $\begin{array}{l}\text { Right 1st molar }\left(6^{\text {th }}\right) \\
\text { Male } \\
\text { Female }\end{array}$ & $\begin{array}{c}91 \\
109\end{array}$ & $\begin{array}{l}28.08 \pm 0.786 \\
27.64 \pm 0.716\end{array}$ & 0.417 & 0.677 \\
\hline $\begin{array}{l}\text { Left 1st molar }\left(6^{\text {th }}\right) \\
\text { Male } \\
\text { Female }\end{array}$ & $\begin{array}{l}100 \\
107\end{array}$ & $\begin{array}{l}29.45 \pm 0.866 \\
28.44 \pm 0.680\end{array}$ & 0.926 & 0.356 \\
\hline $\begin{array}{c}\text { Right } 2 \text { nd molar }\left(7^{\text {th }}\right) \\
\text { Male } \\
\text { Female }\end{array}$ & $\begin{array}{c}96 \\
113\end{array}$ & $\begin{array}{l}24.81 \pm 0.835 \\
24.79 \pm 0.763\end{array}$ & 0.016 & 0.987 \\
\hline $\begin{array}{c}\text { Left 2nd molar }\left(7^{\text {th }}\right) \\
\text { Male } \\
\text { Female }\end{array}$ & $\begin{array}{l}106 \\
113\end{array}$ & $\begin{array}{l}25.83 \pm 0.780 \\
25.40 \pm 0.715\end{array}$ & 0.408 & 0.683 \\
\hline
\end{tabular}

$\mathrm{SE}=$ Standard error $\mathrm{TCI}=$ tooth coronal index; $\mathrm{t}=$ student $\mathrm{t}-$ test $\mathrm{p}<0.05$ is considered significant

Table 2: Comparison of Tooth - Coronal Index (TCI) of the Right and Left Teeth Between both sexes $(n=234)$ 
The correlation between tooth - coronal index (TCI) of the right and the left teeth and age in all studied subjects ( $\mathrm{n}=234$ ) is represented in Table 3. There is positive correlation between TCI and age. The correlation is more in females than males $(0.051-$ $0.261 ; 0.069-0.223$ for premolars \& $0.079-0.245 ; 0.136-0.170$ for molars) respectively. The $2^{\text {nd }}$ right premolar TCI has a higher significant correlation with age in all studied subjects $(\mathrm{p} \leq 0.05)$.

\begin{tabular}{|c|c|c|c|c|c|c|}
\hline \multirow{2}{*}{ Teeth $($ TCI $)$} & \multicolumn{2}{|c|}{ Combined group } & \multicolumn{2}{c|}{ Males } & \multicolumn{2}{c|}{ Females } \\
\cline { 2 - 7 } & $\mathbf{R}$ & $\mathbf{P}$ & $\mathbf{R}$ & $\mathbf{P}$ & $\mathbf{R}$ & $\mathbf{P}$ \\
\hline Right $1^{\text {st }}$ premolar $\left(4^{\text {th }}\right)$ & 0.107 & 0.118 & 0.082 & 0.408 & 0.154 & 0.106 \\
\hline Left $1^{\text {st }}$ premolar $\left(4^{\text {th }}\right)$ & $-0.034-$ & 0.623 & $-0.069-$ & 0.506 & 0.051 & 0.594 \\
\hline Right $2^{\text {nd }}$ premolar $\left(5^{\text {th }}\right)$ & 0.241 & $<0.001^{* * *}$ & 0.223 & $0.027^{\star}$ & 0.261 & $0.005^{* *}$ \\
\hline Left $2^{\text {nd }}$ premolar $\left(5^{\text {th }}\right)$ & 0.085 & 0.221 & $-0.102-$ & 0.322 & 0.237 & $0.012^{\star}$ \\
\hline Right $1^{\text {st }}$ molar $\left(6^{\text {th }}\right)$ & 0.157 & $0.026^{*}$ & 0.138 & 0.191 & 0.172 & 0.073 \\
\hline Left $1^{\text {st }}$ molar $\left(6^{\text {th }}\right)$ & 0.197 & $0.005^{* *}$ & 0.146 & 0.147 & 0.245 & $0.011^{*}$ \\
\hline Right $2^{\text {nd }}$ molar $\left(7^{\text {th }}\right)$ & 0.119 & 0.087 & 0.136 & 0.186 & 0.108 & 0.253 \\
\hline Left $2^{\text {nd }}$ molar $\left(7^{\text {th }}\right)$ & 0.13 & 0.054 & 0.17 & 0.081 & 0.079 & 0.403 \\
\hline
\end{tabular}

$\mathrm{SE}=$ Standard error; $\mathrm{TCI}=$ tooth coronal index; $\mathrm{r}=$ correlation coefficient; $\mathrm{p}<0.05$ is considered significant.

Table 3: Correlation between tooth-coronal index (TCI) of Right and Left Teeth and Age in all Studied Subjects $(\mathrm{n}=234)$

Multivariate logestic regression analysis with the use of most significant tooth - coronal index to determine age is demonstrated in Table 4.

\begin{tabular}{|c|c|c|c|c|c|c|c|c|}
\hline \multirow{2}{*}{ Group } & \multirow{2}{*}{ Variable } & \multirow{2}{*}{ B } & \multirow{2}{*}{ SE } & \multirow{2}{*}{ Beta } & \multirow{2}{*}{$\mathbf{T}$} & \multirow{2}{*}{ Significance } & \multicolumn{2}{|c|}{$\begin{array}{c}95 \% \text { Confidence } \\
\text { Interval for B }\end{array}$} \\
\hline & & & & & & & $\begin{array}{l}\text { Lower } \\
\text { Bound }\end{array}$ & $\begin{array}{l}\text { Upper } \\
\text { Bound }\end{array}$ \\
\hline \multirow[b]{2}{*}{ Combined group } & Constant & 10.940 & 2.947 & & 3.712 & 0.000 & 5.124 & 16.755 \\
\hline & $\begin{array}{l}\text { TCI of right } 2^{\text {nd }} \\
\text { premolar }\left(5^{\text {th }}\right)\end{array}$ & 0.445 & 0.098 & 0.323 & 4.533 & 0.000 & 0.251 & 0.639 \\
\hline \multirow[b]{2}{*}{ Males } & Constant & 18.545 & 4.371 & & 4.243 & 0.000 & 9.870 & 27.220 \\
\hline & $\begin{array}{l}\text { TCI of right } 2^{\text {nd }} \\
\text { premolar }\left(5^{\text {th }}\right)\end{array}$ & 0.329 & 0.146 & 0.223 & 2.250 & 0.027 & 0.039 & 0.620 \\
\hline \multirow[b]{2}{*}{ Females } & Constant & 9.195 & 4.246 & & 2.165 & 0.033 & 0.773 & 17.617 \\
\hline & $\begin{array}{l}\text { TCI of right } 2^{\text {nd }} \\
\text { premolar }\left(5^{\text {th }}\right)\end{array}$ & 0.454 & 0.143 & 0.299 & 3.177 & 0.002 & 0.171 & 0.738 \\
\hline
\end{tabular}

$\mathrm{SE}=$ standard error; $\mathrm{p}=$ significance; $\operatorname{Exp}=$ exponential

Table 4: Multivariate Logestic Regression Analysis with the Use of Significant Tooth - Coronal Index (TCI) to Predict Age

So for determination of age $(\mathrm{Y})$, the following equations are used in combined group; males and females respectively.

Age $($ Combined group $)=10.940+0.445 \mathrm{X}$ combined sample.

Age $($ Male $)=18.545+0.329 \mathrm{X}$ males.

Age $($ Female $)=9.195+0.454 \mathrm{X}$ females.

$\mathrm{X}$ is the TCI of $2^{\text {nd }}$ right premolar tooth.

\section{Discussion}

Assessment of the pulp/tooth index is an indirect quantification of secondary dentin deposition37. The aim of this study is to assess the accuracy of age estimation from the tooth - coronal index (TCI) of mandibular premolars and molars (except wisdom teeth) of both sides using panoramic radiographs and to develop regression equations that can be used in the Egyptians.

The present results revealed that there is no sex difference in TCI. This is in agreement with studies done in Italy by Drusini et al. [24]; Drusini [21]; Zadzinska et al. [38]; in India by Shrestha [9]; in Egypt by Khattab et al. [39] and in Western Australia by Karkhanis et al. [40]. They stated that sex of individual appears to have no significant influence on age estimation, so that sex specific formulae are not necessary for age estimation in specimens of unknown sex. On the other hand this result is on contrary to that of Agematsu et al. [41] in Japan; Igbigbi and Nyirenda [42] in Malawi; who mentioned that gender has a significant influence on age estimation using TCI and hence there is need for sex - specific formulae in the sampled population. They explained this difference by the influence of estrogen on the formation of secondary dentin. Hietala et al. [43] and Silvana et al. [44] reported the existance of an estrogen receptor in odontoblast of human pulp tissues. In addition, Yokose et al. [45] reported that estrogen deficieny promotes the substrate synthesis of odontoblast. These reports suggest that estrogen exerts a strong influence on formation of secondary dentin. 
Moreover; the current work revealed that the mean TCI of premolars is larger than those of molars and it is higher in males than females ( $27.24 \pm 0.077$ to $28.51 \pm 0.755$ in females; $27.26 \pm 0.748$ to $28.66 \pm 0.846$ in males); and $(24.79 \pm 0.763$ to $28.44 \pm 0.680$ in females; $24.81 \pm 0.835$ to $29.45 \pm 0.866$ in males) respectively. This difference is considered to be due to the fact that the mandibular molars have morphological diversity than premolars. So the difference in decrease in pulp chamber volume in different age groups was not clear in molars as in premolars. Also may be because of mandibular premolar teeth are more visible than molars in radiographs. In addition to the overall size of the pulp cavity and lower resolution of the panoramic radiography for molars where the pulp cavity upper limits are sometimes less visible (Drusini [21]). These findings are consistent with that of Igbigbi and Nyirenda [42] in Malawi whom mentioned that the TCI for molars were lower than those of premolars.

Furthermore; to the best of our knowledge, this is the only work that studied the effect of side (either right or left teeth) on TCI. There is significant difference between right and left teeth as regard TCI. This may be due to developmental or morphological changes or the accuracy of radiographs. This finding was in contradiction with other studies done in Italy by Drusini [21], Drusini et al. [24]; Zadzinska et al. [38]; in Malawi by Igbigbi and Nyirenda [42]; in India by Saxena [35]; Chandramala et al. [37]; Bagh et al. [46]; in Egypt by Khattab et al. [38]; Afify et al. [47]; in Western Australia by Karkhanis et al. [40] and in Belgium by Thevissen and Willems [48] which demonstrated that difference between teeth side is negligible in radiographic age estimation and they chose the side where the pulp chamber was more visible. Kvaal et al. [34] applied his study on left side and if due to tooth positioning, tilting or overlapping, insufficient tooth information was available, the corresponding tooth of right side was measured.

Furthermore, there is positive correlation between TCI in the present work and age and the correlation is more in females than males i.e. the index increases with increasing age $(0.051-0.261 ; 0.069-0.223$ for premolars \& $0.079-0.245 ; 0.136-0.170$ for molars) respectively. This is similar to Shrestha' study [9] in India which mentioned that TCI was significantly increased with increased age. While Drusini [21]; Drusini et al. [24]; Zadzinska et al. [38] in Italy; Igbigbi and Nyirenda [42] in Malawi and Karkhanis et al. [40] in Western Australia reported that there were negative correlation between TCI and age. This could be explained by relatively young age of the present work samples as the age ranged from $8-74$ years with mean age of $25.51 \pm$ 0.84 years; so the decraese in pulp cavity due to dentin deposition is not evident. It is more in females than males may be due to hormonal changes.

Moreover, the current results stated that $2^{\text {nd }}$ right premolar tooth is the most significant in the studied groups ( $\mathrm{p} \leq 0.05$ ). This is inconsistent with studies done in Italy by Drusini [21]; Drusini et al. [24] who mentioned that there was no significant differences between either $1^{\text {st }}$ and $2^{\text {nd }}$ premolars or $1^{\text {st }}$ and $2^{\text {nd }}$ molars and there was a strong correlation for molars than premolars in males. Also Zadzinska et al. [38] in Italy proved that male premolars had the highest correlation with age. While it is similar to that of Afify et al. [47] in Egypt which revealed that 2nd premolar was the most closely correlated with the age. Also Igbigbi and Nyirenda [42] in Malawi postulated that correlation was higher for premolar than molar teeth. This may be an expression of the overall size of the pulp cavity. In addition; Agematsu et al. [41] in Japan declared that females showed a stronger correlation between volume ratio of the pulp chamber and age for central incisor and $2^{\text {nd }}$ premolar. Also Chandramala et al. [37] in India proved that upper $2^{\text {nd }}$ premolar had highest correlation followed by lower 1st premolar. In addition Karkhanis et al [40] in Western Australia mentioned that $1^{\text {st }}$ right premolar had the highest correlation.

The variations among individuals as well as across populations and between the sexes; could be attributed to socioeconomic status, cultural and racial differences, genetic differences, difference in behavior, environmental factors, diet and disease (Slaus et al. [49]).

Moreover, the differences between the present results and other studies could be explained by differences in studied populations, difference in sample size and teeth examined in each study.

\section{Conclusion}

From the present work it could be concluded that age estimation from TCI is a precise, non-invasive, not time consuming; not requires highly specialized equipment and applicable to both living and dead individuals. Also the result concluded that gender has no effect on TCI, and there was significant difference between the right and the left teeth so they should be taken into consideration. In addition, the $2^{\text {nd }}$ right premolar TCI was the most significant in Egyptian males; females and combined group. The regression equations should be applied cautiously for different population and time periods.

\section{Acknowledgment}

We acknowledge further studies including wisdom teeth and including larger sample site and covering large geographical areas.

\section{References}

1. Ferenandes M, Pereira D, Braganca P, de Lima SH, Francesquini Junior L et al. (2011) Estimation by Measurements of Developing Teeth: Accuracy of Cameriere's Method on a Brazilian Sample. J Forensic Sci 56: 1616 - 9.

2. Rai B, Kaur J, Cingolani M, Ferrante L, Cameriere R (2010) Age Estimation in Children by Measurement of Open Apices in Teeth: An Indian Formula. Int J Legal Med 124: $237-41$.

3. Cameriere R, Ferrante L, Belcastro MG, Bonfiglioli B, Rastelli E, et al. (2007) Age Estimation by Pulp / Tooth Ratio in Canines by Peri-Apical X - rays. J Forensic Sci 52: 166-70. 
4. Someda H, Saka H, Matsunaga, S, Ide Y, Nakahara K, et al. (2009) Age Estimation Based on Three-Dimensional Measurement of Mandibular Central Incisors in Japanese. Forensic Sci Int 185: $110-4$.

5. Amandeep S, Gorea RK, Singla U (2004) Age Estimation from Physiological Changes of Teeth. J Indian Forensic Sci 26: 0971-3.

6. Joseph CC, Reddy BHS, Cherian NM, Kannan SK, George G, et al. (2013) Intraoral Dental Radiography for Adult Age Estimation: A Reliable Technique. J Indian Academy Oral Medi Radiol 25: 287 - 90.

7. Ohtani S, Yamamoto K (1991) Age Estimation Using the Racemization of Amino Acid in Human Dentin. J Forensic Sci 36: 792-800.

8. Takasaki T, Tsuji A, Ikeda N, Ohishi M (2003) Age Estimation in Dental Pulp DNA Based on Human Telomere Shortening. Int J Legal Med 117: 232-4.

9. Shrestha J (2014) Comparative Evaluation of Two Established Age Estimation Techniques (Two Histological and Radiological) by Image Analysis Software Using Single Tooth. Forensic Res 5: 1-6.

10. Zaher JF, Fawzy IA, Habib SR, Ali MM (2011) Age Estimation from Pulp / Tooth Area Ratio in Maxillary Incisors Among Egyptians Using Dental Radiographic Images. J Forensic Leg Med 18: 62-5.

11. Erbudak HO, Ozbek M, Uysal S, Karabulut E (2012) Application of Kvaal et al's Age Estimation Method to Panoramic Radiographs from Turkish Individuals. Forensic Sci Int 219: 141-6.

12. Lamendin H, Baccino E, Humbert JF, Tavernier JC, Nossintchouk RM, et al. (1992) A Simple Technique for Age Estimation in Adult Corpses: the Two Criteria Dental Method. J Forensic Sci 37: 1373-9.

13. Bang G, Ramm E (1970) Determination of Age in Humans from Root Dentin Transparency. Acta Odontol Scand 28: 3-35.

14. Condon K, Charles DK, Cheverud JM, Buikstra JE (1986) Cementum Annulation and Age Determination in Homo Sapiens. II. Estimates and Accuracy. Am J Phys Anthropol 71: 321-30.

15. Helfman PM, Bada JL (1976) Aspartic Acid Racemization in Dentin as a Measure of Ageing. Nature 262: $279-81$.

16. Bashet M, Acharya AB, Naikmasur VG (2010) Age Estimation in Indians from Pulp / Tooth Area Ratio of Mandibular Canines. Forensic Sci Int $197: 125$.

17. Cameriere R, De Luca S, Aleman I, Ferrante L, Cingolani M (2012) Age Estimation by Pulp / Tooth Ratio in Lower Premolars by Orthopantomography. Forensic Sci Int 214: 105-12.

18. Yuniarti A, Arifin AZ, Wijaya AY, Khotimah WN (2013) An Age Estimation Method to Panoramic Radiographs from Indonesian Individuals. Telkomnika 11: 199-206.

19. Manigandan SC, Sivagami AV (2014) Age Estimation with Dental Radiographs. Res J Pharmaceutical, Biol Chem Sci 5: $1370-6$.

20. Drusini AG (1993) Age Estimation from Teeth Using Soft X-Ray Findings. Anthrop Anz 51: 41-6.

21. Drusini AG (2008) The Coronal Pulp Cavity Index: A Forensic Tool for Age Determination in Human Adults. Cuad Med Forense 14: $235-49$.

22. Ayad CE, Hamid HM, Abdalla EA, Kajoak SA (2014): Estimation of Age for Sudanese Adults Using Orthopantomographs. Glob J Med Res 14: 7-14.

23. Sharma R, Srivastava A (2010) Radiographic Evaluation of Dental Age of Adults using Kvaal's Method. J Forensic Dent Sci 2: $22-6$.

24. Drusini AG, Toso O, Ranzato C (1997) The Coronal Pulp Cavity Index: A biomarker for Age Determination in Human Adults. Am J Phys Anthropol 103: 35363.

25. Schour I, Massler M (1941) The Development of the Human Dentition. J Am Dent Assoc 28:1153-60.

26. Demirjian A, Goldstein H, Tanner JM (1973) A New System of Dental Age Assessment. Hum Biol 45: $211-27$.

27. Ikeda N, Umetsu K, Kashimura S, Suzuki T, Oumi M (1985) Estimation of Age from Teeth with Their Soft X-Ray Findings. JPN J For Med 39: 244-50.

28. Gustafson G (1950) Age Determinations on Teeth. J Am Dent Assoc 41: 45-54.

29. Kilian J (1975) The Technique of Thin Sections of Teeth. Czechoslovak Dentistry 75: 24-8.

30. Kashyap VK, Koteswara NR (1990) A Modified Gustafson Method of Age Estimation from Teeth. Forensic Sci Int 47: $237-47$.

31. Cameriere R, Ferrante L, Cingolani M (2004) Variations in Pulp/Tooth Area Ratio as an Indicator of Age: a Preliminary Study. J Forensic Sci 49 : $317-9$.

32. Cameriere R, Ferrante L, Cingolani M (2004) Precision and Reliability of Pulp/ Tooth Area Ratio (RA) of Second Molar as Indicator of Adult Age. J Forensic Sci 49: 1319-23.

33. Cameriere R, Brogi G, Ferrante L, Mirtella D, Vultaggio C, et al. (2006) Reliability in Age Determination by Pulp/Tooth Ratio in Upper Canines in Skeletal Remains. J Forensic Sci 51: 861-4.

34. Kvaal SI, Kolltveit KM, Thomsen IO, Solheim T (1995) Age Estimation of Adults from Dental Radiographs. Forensic Sci Int 74 : $175-85$.

35. Saxena S (2011) Age estimation of Indian Adults from Orthopantomographs. Braz Oral Res 25: 225-9.

36. Chandramala R, Sharma R, Khan M, Srivastava A (2012) Application of Kvaal's Technique of Age Estimation on Digital Panoramic Radiographs. Dentistry $2: 142-7$.

37. Vazquez L, Nizamaldin Y, Combescure C, Nedir R, Bischof M, et al. (2013) Accuracy of Vertical Height Measurements on Direct Digital Panoramic Radiographs Using Posterior Mandibular Implants and Metal Balls as Reference Objects. Dentomaxillofac Radiol 42: doi: 10.1259/dmfr.20110429.

38. Zadinska E, Drusini AG, Carrara N (2000) The Comparison Between Two Age Estimation Methods Based on Human Teeth. Przeglad Antropologiczny - Anthropological Review 63: 95-101.

39. Khattab NAF, Marzouk HM, AbdelWahab TM (2013) Application of Tooth Coronal Index for Age Estimation Among Adult Egyptians. Schoolary Res 15.

40. Karkhanis S, Mack P, Franklin D (2013) Age Estimation Standards for a Western Australian Population Using the Coronal Pulp Cavity Index. Forensic Sci Int 231: 412e1-6.

41. Agematsu H, Someda H, Hashimoto M, Matsunaga S, Abe S, et al. (2010) Three Dimensional Observation of Decrease in Pulp Cavity Volume Using Micro - CT: Age Related Change. Bull Tokyo Dent Coll 51: 1-6.

42. Igbibi PS, Nyirenda SK (2005) Age Estimation of Malawian Adults from Dental Radiographs. WAJM 24: $329-33$.

43. Heitala EL, Larmas M, Salo T (1998) Localization of Estrogen Receptor related antigen in human odontoblast. J Dent Res 77: 1384-7.

44. Silvana J, Goranka PM, Jasna TH, Ivana M, Sanja S, et al. (2003) Estrogen Receptors in Human Pulp Tissue. Oral Surg Oral Med Oral Pathol 95: 340-4.

45. Yokose S, Zhungfeng C, Tajima Y, Fujieda K, Katayama I, et al. (1998) The Effect of Estrogen Deficiency on Glycosylation of Odontoblasts in Rats. J Endod 24: $645-7$. 
46. Bagh T, Chatra L, Shenai P, Veena KM, Rao PK, et al. (2014) Age Estimation Using Cameriere Seven Teeth Method with Indian Specific Formula in South Indian Children. Int J Advanced Health Sci 1: 2-10.

47. Afify MM, Zayet MK, Mahmoud NF, Ragab AR (2014) Age Estimation from Pulp / Tooth Area Ratio in Three Mandibular Teeth by Panoramic Radiographs: Study of an Egyptian Sample. Forensic Res 5: 3.

48. Thevissen PW, Galiti D, Willems G (2012) Human Dental Age Estimation Combining Third Molar(s) Development and Tooth Morphological Age Predictors. Int J Legal Med 126: 883-7.

49. Slaus M, Strinoviae D, Skaviae J, Petroveeki V (2003) Discriminate Function Sexing of Fragmentary and Complete Femora: Standards of Contemporary Croatia. J Forensic Sci 48: 509-12.

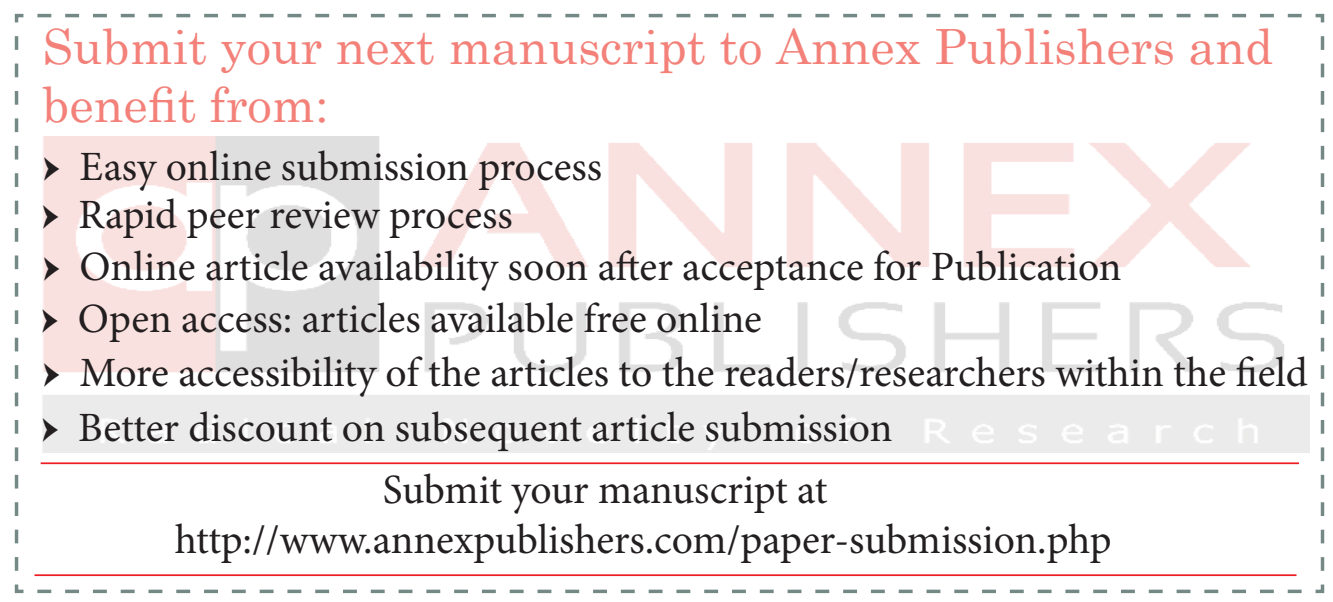

